\title{
Epidemiological survey of tularemia in Ilam Province, west of Iran
}

\author{
Saber Esmaeili 1,2,3, Ahmad Ghasemi ${ }^{1,2,3}$, Razi Naserifar ${ }^{4}$, Ali Jaliliann ${ }^{4}$, Leila Molaeipoor ${ }^{5,6,1}$, Max Maurin ${ }^{7,8}$ and \\ Ehsan Mostafavi ${ }^{1,2^{*}}$
}

\begin{abstract}
Background: Francisella tularensis is the causative agent of tularemia in humans and a large number of animal species. Considering recent evidence of the circulation of this bacterium in different parts of Iran, especially in the western provinces, the aim of current study was to determine the tularemia seroprevalence in the human population living in llam Province.

Methods: In 2015, 360 serum samples were collected from five groups of people: ranchers $(n=112)$, farmers $(n=$ 79), butchers and slaughterhouse workers $(n=61)$, Nature Conservation Officers ( $n=34)$, and referents of medical diagnostic laboratories $(n=74)$. These samples were tested for the presence of anti- $F$. tularensis IgG antibodies using the ELISA method.

Results: According to the ELISA manufacturer cutoffs, we found that 10 (2.78\%) and 9 (2.5\%) sera, respectively, were positive or borderline for $F$. tularensis lgG antibodies. The highest tularemia seroprevalence was observed among farmers (7.59\%).

Conclusions: Our results strongly support the circulation of tularemia in llam Province. Because no human tularemia case has been reported so far in this province, we recommend specific education programs to increase knowledge of local health care professionals about this important zoonotic disease.
\end{abstract}

Keywords: Tularemia, Francisella tularensis, Seroprevalence, Iran, High-risk population

\section{Background}

Francisella tularensis is a Gram-negative, intracellular bacterium, causing tularemia in humans and many animal species [1]. This pathogen is considered a biological threat agent because it can induce severe diseases even at a low infectious dose, it can be spread by aerosols, it can survive for months in water and soil environments, only a limited number of antibiotics can be used for treatment, and no vaccine is available for prevention of tularemia [2]. The species $F$. tularensis classically includes four subspecies: tularensis (type A), holarctica (type B), mediasiatica and novicida. Only the two

\footnotetext{
* Correspondence: mostafavi@pasteur.ac.ir; mostafaviehsan@gmail.com 'Department of Epidemiology and Biostatistics, Research Centre for Emerging and Reemerging infectious diseases, Pasteur Institute of Iran, No. 69, Pasteur Ave, Tehran 1316943551, Iran

${ }^{2}$ National Reference laboratory for diagnosis and research on Plague,

Tularemia and Q fever, Research Centre for Emerging and Reemerging

infectious diseases, Pasteur Institute of Iran, Akanlu, Kabudar Ahang,

Hamadan, Iran

Full list of author information is available at the end of the article
}

former subspecies are considered causative agents of tularemia in the world. Type A strains are mostly found in North America. Type B strains are spread throughout the northern hemisphere, and thus is the only subspecies causing tularemia in Europe and Asia [3]. Type B strains have been recently detected in Australia [4].

F. tularensis can infect many vertebrate and invertebrate animals. Small rodents and lagomorphs (rabbits and hares) are considered the primary source of human infections. Domestic animals (especially lambs and cats in the United States) can occasionally be infected with (or carriers of) F. tularensis, and may transmit the disease to humans [2]. At-risk groups for tularemia include laboratory staff, farmers, ranchers, hunters, veterinarians, Nature Conservation Officers, butchers and slaughterhouse workers [5]. The routes of tularemia transmission to humans are numerous: direct contact with infected animals (especially hares); consumption of F. tularensis-contaminated meat or water; arthropod bites (mainly ticks, 
and mosquitoes in specific areas); and exposure to a contaminated water or soil environment $[1,3,6-8]$.

The clinical manifestations of tularemia in humans vary from an asymptomatic infection to very severe diseases, which may lead to death [9]. After a mean incubation period of 3-5 days, the disease begins often with flu-like symptoms such as fever, chills, weakness, myalgia, joint pain, sore throats and headache. Then, depending on the route of infection, the disease may evolve to one of six main clinical forms: glandular, ulceroglandular, oropharyngeal, oculoglandular, pneumonic, and typhoidal [3]. Type A infections are usually more severe than type $\mathrm{B}$, and the mortality rates in untreated patients are $10-40$ and $1 \%$, respectively [9].

In Iran, the first human tularemia case was reported in 1981 from the western part of the country (Kurdistan province). The patient suffered from a glandular form of tularemia, with fever, chills, myalgia, fatigue, headache, anorexia and severe enlargement of the inguinal lymph nodes [10]. Since then, no other tularemia case has been reported in Iran [5]. Recent seroepidemiological studies, however, have reported significant prevalence of anti- $F$. tularensis antibodies in the Iranian population [11-13]. In a recent study, F. tularensis has been detected in rabbits and rodents in Iran by molecular methods [14]. On the other hand, Turkey (a neighboring country in northwestern Iran), reported annually 400-2000 human tularemia cases during the 2009-2012 period [8]. In fact, very few recent studies have evaluated the status and epidemiology of tularemia in Iran. The aim of the current study was to investigate the tularemia seroprevalence among high-risk groups of individuals in the western province of Ilam.

\section{Methods}

\section{Study area}

This study was conducted in Ilam Province, western Iran, in 2015 (Fig. 1). The province population is approximately 600,000 , and it is located in a mountainous region with a Mediterranean climate. This province covers an area of $20,000 \mathrm{~km}^{2}$, about $1.2 \%$ of Iran.

\section{Sampling}

Blood samples were collected in three counties located on the western part of Ilam Province: Ilam, Dehloran and Mehran (Table 1). Patients included in the study were over 18 years old and belonged to one of four atrisk populations: ranchers, farmers, butchers and slaughterhouse workers, and Nature Conservation Officers. Referents of medical diagnostic laboratories (healthy people without any clinical symptoms) from the same area were selected as the control group. Informed consent was obtained from all selected individuals. For each participant, a $5 \mathrm{ml}$ blood sample was taken and all

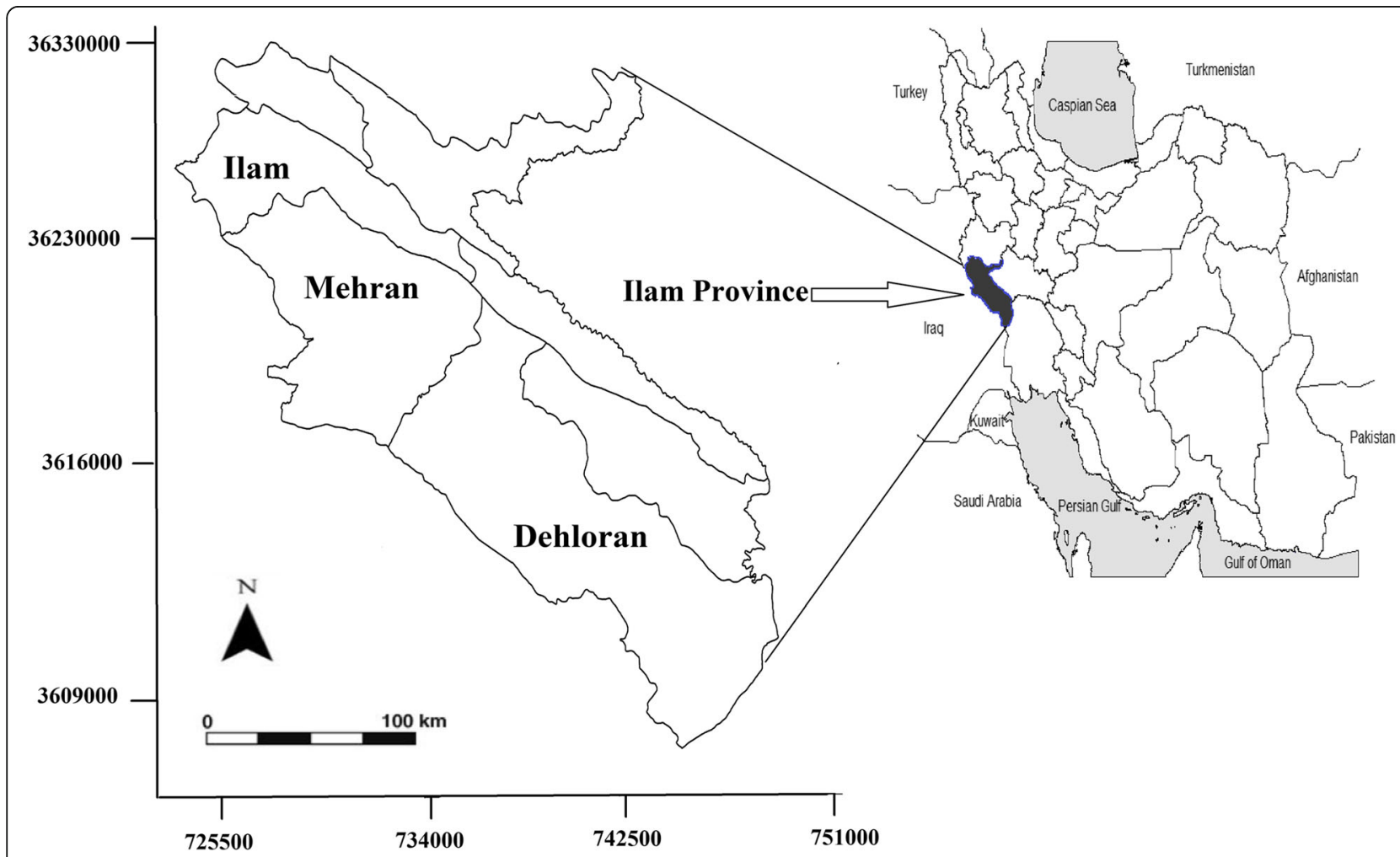

Fig. 1 Sampling site of Ilam Province in West of Iran to study tularemia infection, 2015 
Table 1 Population of the sampling sites of the studied areas in llam Province, western llam

\begin{tabular}{llllll}
\hline & & \multicolumn{3}{l}{ Area of residence } & \\
\cline { 3 - 5 } County & Population & Urban & Rural & Nomads & No. of samples \\
\hline llam & 235,144 & 199,861 & 35,230 & 53 & 141 \\
Dehloran & 65,630 & 41,183 & 24,396 & 51 & 100 \\
Mehran & 29,797 & 19,186 & 10,516 & 95 & 118 \\
\hline
\end{tabular}

samples transferred immediately to the laboratory for serum extraction. Serum samples were then stored at $20^{\circ} \mathrm{C}$. All sera were sent to the National Reference Laboratory for Plague, Tularemia and Q fever in the Pasteur Institute of Iran for serological investigations.

Demographic and epidemiological data from people included in the study were collected using two questionnaires. The demographic questionnaire included the following information: age, sex, education, occupation, marital status, county and place of residence. The second questionnaire collected risk factors for F. tularensis exposure: owning animals; hunting; consumption of meat from wild animals; contact with a sick animal or its corpse; bites from arthropods (ticks, fleas and mosquitoes); splashing blood or other body fluids on the face or body; consumption of non-pasteurized milk or dairy products; cutting hands or other parts of the body during work with animals; use of personal protective equipment; and in general knowledge of zoonosis and protective measures against this infectious risk.

\section{Serology}

All sera were tested for the presence of $F$. tularensis IgG antibodies using the commercial ELISA kit (Serion ELISA classic Francisella tularensis, Virion/Serion GmbH, Würzburg, Germany) according to the manufacturer's instructions. The retrieved ODs were evaluated according to the protocols of Serion/Verion and the IgG was reported in a quantitative way. The titer of IgG antibody was calculated using a logistic- log model calculation in $\mathrm{U} / \mathrm{ml}$. Using cutoff titers advocated by the manufacturer serological titers were reported as positive (antibody titer $>15 \mathrm{U} / \mathrm{ml}$ ), borderline $(10-15 \mathrm{U} / \mathrm{ml})$, or negative $(<10 \mathrm{U} / \mathrm{ml})$.

\section{Statistical analysis}

The data was analyzed using Stata software version 11 (StataCorp, College Station, TX, USA). The potential influence of tularemia risk factors on the observed seroprevalence rates was investigated by logistic regression analysis. $P$-values less than 0.05 were considered statistically significant.

\section{Results}

We collected 360 serum samples from the five studied groups, including ranchers $(n=112)$, farmers $(n=79)$, butchers and slaughterhouse workers $(n=61)$, Nature Conservation Officers $(n=34)$, and referents of medical diagnostic laboratories $(n=74)$. Among these participants, $76.29 \%$ were males, $89.86 \%$ were married, and $45.18,44.88$ and $10.44 \%$ were living in urban, rural or nomadic areas, respectively. The mean $( \pm$ SD) age of the tested subjects was $40.54( \pm 13.55)$ years old (range 18 to 78 years).

Of the 367 sera samples, $10(2.78 \%)$ and $9(2.5 \%)$ of participants were considered positive or borderline for anti-F. tularensis IgG antibodies, respectively. No present or past history of tularemia could be recorded in seropositive individuals. The highest and the lowest tularemia seroprevalence were observed in farmers (7.59\%) and Nature Conservation Officers (0\%), respectively (Table 2). Seroprevalence was almost the same in all the studied counties and in both genders. The age 31-40 years and over 50 years old had the highest and lowest seroprevalence, respectively. None of the investigated risk factors had a statistically significant relationship with tularemia seroposivity (Table 3 ).

\section{Discussion}

Our study strongly supports the presence of tularemia in Ilam Province. The overall tularemia seroprevalence among different populations studied was $2.78 \%$, although we found a seroprevalence of $7.59 \%$ in farmers, which are probably more exposed to the $F$. tularensis animal reservoir. A much higher seroprevalence (14.7\%) was previously reported in Kurdistan Province, western Iran [12]. A seroprevalence of $6.5 \%$ was also found in butchers and slaughterhouse workers in the Sistan and Baluchestan province, southeast of Iran [13].

The prevalence of tularemia in different parts of the world is highly dependent on people culture and lifestyle, although ecological conditions have an irrefutable role [15-17]. In Iran, the highest prevalence of tularemia has been observed among hunters (18\%), and contact with wildlife has been shown to be a significant risk factor [12]. In the present study, there was no statistically significant relationship between tularemia seroprevalence and hunting or eating meat from wildlife animals. A rarer practice of hunting in the province of Ilam compared to other provinces of Iran may be one of the reasons for lower exposure to $F$. tularensis and lower tularemia seroprevalence.

Living in rural areas is usually considered a major risk factor for tularemia because of more frequent contact with wildlife animals [18, 19]. However, we found only weak difference of seroprevalence between rural and urban people of the study (3.77\% versus $2.53 \%$, NS). Similar studies in Iranian Kurdistan [12] and Turkey [20] have also reported non-significant differences between rural and urban populations. This probably means 
Table 2 Results from the bivariate logistic regression analysis of demographic predictors of tularemia using unadjusted odds ratios (ORs)

\begin{tabular}{|c|c|c|c|c|}
\hline Variable & Category & Number (\% Positive Test) & Crude OR $(95 \% \mathrm{Cl})$ & P-Value \\
\hline \multirow[t]{5}{*}{ Occupation } & Referents of the medical diagnostic labs & $74(1.35)$ & 1.00 & \\
\hline & Rancher & 112(0.89) & $0.67(0.02-26.34)$ & 0.802 \\
\hline & Butcher & $61(3.28)$ & $2.49(0.19-74.92)$ & 0.510 \\
\hline & Nature Conservation Officers & $34(0.00)$ & $0.0(0.00-41.91)$ & 0.688 \\
\hline & Farmer & 79(7.59) & $6.02(0.86-142.6)$ & 0.075 \\
\hline \multirow[t]{2}{*}{ Gender } & Male & 275(2.91) & 1.00 & \\
\hline & Female & $85(2.35)$ & $0.80(0.11-3.56)$ & 0.84 \\
\hline \multirow[t]{4}{*}{ Age (Year) } & $18-30$ & 101(1.98) & 1.00 & \\
\hline & $31-40$ & $97(5.15)$ & $2.68(0.51-20.35)$ & 0.259 \\
\hline & $41-50$ & $80(2.50)$ & $1.27(0.13-12.4)$ & 0.826 \\
\hline & $>50$ & $81(1.23)$ & $0.63(0.02-8.38)$ & 0.759 \\
\hline \multirow[t]{3}{*}{ Area of residence } & Urban & $158(2.53)$ & 1.00 & \\
\hline & Rural & 159(3.77) & $1.51(0.41-6.16)$ & 0.549 \\
\hline & Nomads & $39(0.00)$ & $0.0(0.0-4.55)$ & 0.411 \\
\hline \multirow[t]{5}{*}{ Education } & Illiterate & $81(2.47)$ & 1.00 & \\
\hline & Primary & $76(6.58)$ & $2.76(0.53-21.13)$ & 0.245 \\
\hline & Secondary & 46(4.35) & $1.79(0.18-17.66)$ & 0.594 \\
\hline & Diploma & $92(1.09)$ & $0.44(0.01-5.82)$ & 0.553 \\
\hline & Academic & $63(0.00)$ & $0.25(0.01-5.31)$ & 0.314 \\
\hline \multirow[t]{2}{*}{ Marriage } & Single & $36(5.56)$ & 1.00 & \\
\hline & Married & $324(2.47)$ & $2.31(0.32-10.5)$ & 0.331 \\
\hline \multirow[t]{3}{*}{ County } & Dehloran & 100(3.00) & 1.00 & \\
\hline & Mehran & $118(2.54)$ & $0.85(0.14-5.03)$ & 0.849 \\
\hline & Ilam & $141(2.84)$ & $0.95(0.19-5.17)$ & 0.933 \\
\hline
\end{tabular}

that people living in urban areas keep frequent contact with the rural environment. As in other studies [12, 13, $18]$, gender was not associated with a significant difference in tularemia seroprevalence. More surprisingly, a higher age was not associated with a higher seroprevalence of tularemia in our present study, while previous ones have shown a higher seroprevalence in older people $[12,18]$. A possible explanation could be that tularemia has been reintroduced recently in Ilam Province, and thus middle-aged people, most at risk of tularemia, have higher seroprevalence.

Tularemia prevalence also depends on the main reservoirs and modes of transmission of $F$. tularensis to humans and animals. Several studies in Turkey have shown that tularemia outbreaks have occurred in recent years because of the consumption of contaminated water. A water-borne tularemia infection usually concerns a large population, of all ages, and all year round. Water sources are usually contaminated by the wildlife reservoir, including small rodents that are carriers of or infected by $F$. tularensis. The role of migratory birds has also been taken into consideration, because their respiratory secretions and feces can cause water contamination [21, 22]. Tularemia outbreaks have never been reported in Iran, which is not in favor of extensive water reservoir of tularemia. The role of ticks in the transmission of tularemia should be further evaluated as this mode of transmission is highly prevalent in most tularemia endemic countries.

Finally, the absence of any statistically significant risk factors in our study may be related to the small number of seropositive participants (10 out of 367 studied individuals). Therefore, it is recommended that the number of participants be higher in similar studies in areas with low tularemia seroprevalence.

Although we found anti-F. tularensis antibodies in several serum samples, no clinical case of tularemia has been reported so far in Ilam Province. The Serion ELISA method for detection of IgG antibodies directed against F. tularensis antigen is considered highly sensitive and specific [23]. Thus, our results highly suggest that tularemia is underdiagnosed in Ilam Province. F. tularensis strains circulating in Iran should probably be of type B as in the rest of Asia [1]. Type B strains usually cause 
Table 3 Relationship between behavioral characteristics and tularemia seropositivity in Ilam Province, 2015

\begin{tabular}{|c|c|c|c|}
\hline Variable & $\begin{array}{l}\text { Number having the variable } \\
\text { (\%Seropositive) }\end{array}$ & $\begin{array}{l}\text { Number not having the Variable(\% } \\
\text { Seropositive) }\end{array}$ & $\begin{array}{l}P \text { - } \\
\text { value }\end{array}$ \\
\hline Attitude $^{a}$ & $245(2.86)$ & $113(2.65)$ & 0.885 \\
\hline Splashing animal fluids on face/body & $202(2.97)$ & $99(3.03)$ & 0.951 \\
\hline Exposure to ill or dying animals & $86(0.00)$ & 274(3.65) & 0.063 \\
\hline Hunting/consumption of wild animal meat & 228(3.95) & $130(0.77)$ & 0.148 \\
\hline Rabbit & $8(0.00)$ & 115(0.87) & 0.935 \\
\hline Partridge & $94(1.06)$ & $29(0.00)$ & 0.764 \\
\hline Fox & $1(0.00)$ & $124(0.81)$ & 0.992 \\
\hline Mongoose & $2(0.00)$ & $121(0.83)$ & 0.984 \\
\hline Emigrant/feral Birds & $44(0.00)$ & $79(1.27)$ & 0.642 \\
\hline Mountain animals & $88(1.14)$ & $35(0.00)$ & 0.715 \\
\hline Others ${ }^{* *}$ & $3(0.00)$ & $121(0.83)$ & 0.976 \\
\hline Keeping animals & $217(2.76)$ & 139(2.88) & 0.937 \\
\hline Cattle & 77(3.90) & $143(2.10)$ & 0.466 \\
\hline Goats and sheep & $197(2.54)$ & 23(4.35) & 0.610 \\
\hline Dogs and cats & $100(2.00)$ & $119(2.52)$ & 0.832 \\
\hline Rabbit & $8(0.00)$ & $212(2.83)$ & 0.799 \\
\hline Horse / Donkey & $60(3.33)$ & 160(3.12) & 0.522 \\
\hline $\begin{array}{l}\text { Hunting Meat Consumption ( } 5 \text { times or } \\
\text { more) }\end{array}$ & $21(0.00)$ & $98(2.02)$ & 0.677 \\
\hline Unpasteurized milk and dairy & $179(2.23)$ & 179(3.35) & 0.544 \\
\hline Mosquito bites & $247(2.83)$ & $107(2.80)$ & 0.865 \\
\hline Tick bites & $32(0.00)$ & $322(3.11)$ & 0.383 \\
\hline Flea bites & $42(0.00)$ & $311(3.22)$ & 0.277 \\
\hline Using disinfection tools & $74(1.35)$ & $81(1.23)$ & 0.955 \\
\hline Disinfection of hands/face & $75(1.33)$ & $80(1.25)$ & 0.961 \\
\hline Length of employment (20 years or more) & $129(2.33)$ & 154(4.55) & 0.339 \\
\hline Cutting hand/year (5 times or more) & $17(5.88)$ & $226(3.54)$ & 0.621 \\
\hline
\end{tabular}

${ }^{\mathrm{a} S e e}$ themselves as high risk for Zoonosis diseases

infections of mild to moderate severity that can remained undiagnosed $[18,24]$. On the other hand, very low attention has been paid to tularemia in training programs for physicians in Iran, and laboratories capable of confirming tularemia cases have only existed for a few years in Iran. It may be assumed that some tularemia patients have been treated blindly with antibiotics [12]. Therefore, failure to report human tularemia cases in Ilam Province is partly justifiable and does not necessarily mean that the disease is absent.

According to the high prevalence of tularemia in the neighboring countries of Iran, including Azerbaijan [18], Armenia [25] and Turkey [26], and the high tularemia seroprevalence we found in the present and in previous studies, there is a high potential for human infections with $F$. tularensis occurring in different parts throughout the country. Therefore, tularemia should be considered as a differential diagnosis in patients suffering from infectious diseases that have compatible clinical manifestations. Continuous monitoring of the presence of this bacterium should be carried out in different parts throughout Iran. Furthermore, to identify the potential reservoirs of $F$. tularensis, studies should be conducted to isolate this bacterium from various sources such as water and wild rodents.

One of the limitations of this study was the lack of an appropriate occupational group representing the general population. Referents of medical diagnostic labs were selected as the control group because of the possibility of taking blood samples from them. However, they may not be a representative sample of the general population. Nonetheless, the non-significant difference in the tularemia seroprevalence observed in this group compared to the other occupational groups may indicate that risk of exposure to F. tularensis in Ilam Province is unrelated to professional activities. Also, although the ELISA method 
has a high sensitivity and specificity for detection of anti-F. tularensis antibodies and this test has been previously used for seroepidemiological studies, other methods such as western blot, culture and PCR tests are required to confirm tularemia diagnosis $[27,28]$.

\section{Conclusions}

Based on results of the present study and previous literature $[5,29,30]$, tularemia is probably endemic in Iran. Further studies are needed to confirm the occurrence of human tularemia cases and evaluate their true incidence in Iran. Physicians and other health care professionals must be further sensitized about this zoonotic risk to achieve this goal.

\section{Acknowledgements}

We would like to express our gratitude from staff of deputy of health in Ilam University of Medical Sciences for their support in sampling.

\section{Authors' contributions}

EM and SE designed the study and had full access to the data. EM undertook full responsibility for the data, accuracy of analysis, and final decision-making for submission. EM and SE designed the study. SE, RN and AJ collected the data. AJ and RN conducted data management. SE and AG contributed to providing of laboratory results. EM and LM conducted the statistical analysis. ES, EM and MM drafted the manuscript. All authors contributed to the acquisition, analysis, or interpretation of data. All authors have read and approved the manuscript.

\section{Funding}

This study was supported by Pasteur Institute of Iran and the Center for Communicable Disease Control of Iranian Ministry of Health (Grant No. 810). The funders had no role in the study design, data collection and analysis, decision to publish, or preparation of the manuscript.

\section{Availability of data and materials}

All data generated or analyzed during this study are included in this manuscript. The datasets used and/or analyzed during the present research project are available from the corresponding author upon reasonable request.

\section{Ethics approval and consent to participate}

The scientific committee and the medical ethics committee of Pasteur Institute of Iran approved the study. All adult subjects submitted an informed written consent

\section{Consent for publication}

Not applicable.

\section{Competing interests}

The authors declare that they have no competing interests.

\section{Author details}

'Department of Epidemiology and Biostatistics, Research Centre for Emerging and Reemerging infectious diseases, Pasteur Institute of Iran, No. 69, Pasteur Ave, Tehran 1316943551, Iran. ${ }^{2}$ National Reference laboratory for diagnosis and research on Plague, Tularemia and Q fever, Research Centre for Emerging and Reemerging infectious diseases, Pasteur Institute of Iran, Akanlu, Kabudar Ahang, Hamadan, Iran. ${ }^{3}$ Department of Bacteriology, Faculty of Medical Sciences, Tarbiat Modares University, Tehran, Iran. ${ }^{4}$ Department of Parasitology, Faculty of Health, Ilam University of Medical Sciences, Ilam, Iran. ${ }^{5}$ Department of Epidemiology, School of Public Health, Iran University of Medical Sciences, Tehran, Iran. ${ }^{6}$ Student Research Committee, Faculty of Public Health Branch, Iran University of Medical Sciences, Tehran, Iran. ${ }^{7}$ Centre National de Référence Francisella tularensis, Laboratoire de Bactériologie, Institut de Biologie et de Pathologie, CHU Grenoble Alpes,
Grenoble, France. ${ }^{8}$ TIMC-IMAG, CNRS/UGA, UMR5525, Université Grenoble Alpes, Grenoble, France.

Received: 26 January 2019 Accepted: 22 May 2019

Published online: 07 June 2019

\section{References}

1. Sjöstedt A. Tularemia: history, epidemiology, pathogen physiology, and clinical manifestations. Ann N Y Acad Sci. 2007:1105(1):1-29.

2. Maurin M. Francisella tularensis as a potential agent of bioterrorism? Expert Rev Anti-Infect Ther. 2015;13(2):141-4.

3. Maurin M, Gyuranecz M. Tularaemia: clinical aspects in Europe. Lancet Infect Dis. 2016:16(1):113-24.

4. Jackson J, McGregor A, Cooley L, Ng J, Brown M, Ong CW, Darcy C, Sintchenko V. Francisella tularensis subspecies holarctica, Tasmania, Australia, 2011. Emerg Infect Dis. 2012;18(9):1484-6.

5. Zargar A, Maurin M, Mostafavi E. Tularemia, a re-emerging infectious disease in Iran and neighboring countrie. Epidemiol Health. 2015;37:1-6.

6. Rydén $P$, Björk R, Schäfer ML, Lundström JO, Petersén B, Lindblom A, Forsman M, Sjöstedt A, Johansson A. Outbreaks of tularemia in a boreal forest region depends on mosquito prevalence. J Infect Dis. 2012;205(2): 297-304.

7. Maurin M, Pelloux I, Brion JP, Del Banõ J-N, Picard A. Human tularemia in France, 2006-2010. Clin Infect Dis. 2011;53(10):e133-41.

8. Gürcan Ş. Epidemiology of tularemia. Balkan Med J. 2014;31:3-10.

9. Hepburn MJ, Simpson AJ. Tularemia: current diagnosis and treatment options. Expert Rev Anti-Infect Ther. 2008;6(2):231-40.

10. Karimi Y, Salarkia F, Ghasemi M. Tularemia: first human case in Iran. J Med Counc Iran. 1981:8:134-41.

11. Khoshdel A, Saedi Dezaki E, Ganji F, Habibian R, Imani R, Taheri E, Nikkhah A First seroprevalence survey of children with tularemia infection in Chaharmahal va Bakhtiari province, Iran. Iran J Pathol. 2014;9(1):23-7.

12. Esmaeili S, Gooya MM, Shirzadi MR, Esfandiari B, Amiri FB, Behzadi MY, Banafshi O, Mostafavi E. Seroepidemiological survey of tularemia among different groups in western Iran. Int J Infect Dis. 2014;18:27-31.

13. Esmaeili S, Esfandiari B, Maurin M, Gouya MM, Shirzadi MR, Amiri FB, Mostafavi E. Serological survey of tularemia among butchers and slaughterhouse workers in Iran. Trans R Soc Trop Med Hyg. 2014:108(8):5168.

14. Mostafavi E, Ghasemi A, Rohani M, Molaeipoor L, Esmaeili S, Mohammadi Z, Mahmoudi A, Aliabadian M, Johansson A. Molecular survey of tularemia and plague in small mammals from Iran. Front Cell Infect Microbiol. 2018;8:215.

15. Helvacı S, Gedikoğlu S, Akalın H, Oral H. Tularemia in Bursa, Turkey: 205 cases in ten years. Eur J Epidemiol. 2000;16(3):271-6.

16. Gürcan \$̧, Tatman Otkun M, Otkun M, Arıkan O, Özer B, Gedikoğlu S. Bolu-Gerede-Yazıkara Köyü'nde Tularemi Epidemisi. İnfeksiyon Derg. 2003;17(2):145-9.

17. Anda P, Del Pozo JS, García JD, Escudero R, Peña FG, Velasco ML, Sellek RE, Chillarón MJ, Serrano LS, Navarro JM. Waterborne outbreak of tularemia associated with crayfish fishing. Emerg Infect Dis. 2001;7(3 Suppl):575.

18. Clark DV, Ismailov A, Seyidova E, Hajiyeva A, Bakhishova S, Hajiyev H, Nuriyev T, Piraliyev S, Bagirov S, Aslanova A. Seroprevalence of tularemia in rural Azerbaijan. Vector-Borne Zoonotic Dis. 2012;12(7):558-63.

19. Dedeoğlu GK, Guercan S, Eskiocak M, Kilic H, Kunduracilar H. Investigation of tularemia seroprevalence in the rural area of Thrace region in Turkey. Mikrobiyol Bul. 2007:41(3):411-8.

20. Yazgı H, Uyanık M, Ertek M, Kılıç S, Kirecci E, Ozden K, Ayyıldız A. Tularemia seroprevalence in the risky population living in both rural and urban areas of Erzurum. Mikrobiyol Bul. 2011:45(1):67-74.

21. Gurcan S, Eskiocak M, Varol G, Uzun C, Tatman-Otkun M, Sakru N, Karadenizli A, Karagol C, Otkun M. Tularemia re-emerging in European part of Turkey after 60 years. Jpn J Infect Dis. 2006;59(6):391-3.

22. Leblebicioglu H, Esen S, Turan D, Tanyeri Y, Karadenizli A, Ziyagil F, Goral G. Outbreak of tularemia: a case-control study and environmental investigation in Turkey. Int J Infect Dis. 2008;12(3):265-9.

23. Chaignat V, Djordjevic-Spasic M, Ruettger A, Otto P, Klimpel D, Müller W, Sachse K, Araj G, Diller R, Tomaso H. Performance of seven serological assays for diagnosing tularemia. BMC Infect Dis. 2014;14(1):234.

24. Feldman KA, Stiles-Enos D, Julian K, Matyas BT, Telford SR III, Chu MC, Petersen LR, Hayes EB. Tularemia on Martha's vineyard: seroprevalence and occupational risk. Emerg Infect Dis. 2003;9(3):350. 
25. Melikjanyan S, Palayan K, Vanyan A, Avetisyan L, Bakunts N, Kotanyan M, Guerra M. Human cases of tularemia in Armenia, 1996-2012. Am J Trop Med Hyg. 2017;97(3):819-25.

26. Kilic S, Birdsell DN, Karagöz A, Çelebi B, Bakkaloglu Z, Arikan M, Sahl JW, Mitchell C, Rivera A, Maltinsky S. Water as source of Francisella tularensis infection in humans, Turkey. Emerg Infect Dis. 2015;21(12):2213.

27. Porsch-Özcürümez M, Kischel N, Priebe H, Splettstösser W, Finke E-J, Grunow R. Comparison of enzyme-linked immunosorbent assay, Western blotting, microagglutination, indirect immunofluorescence assay, and flow cytometry for serological diagnosis of tularemia. Clin Diagn Lab Immunol. 2004;11(6):1008-15.

28. Schmitt P, Splettstoesser W, Porsch-Özcürümez M, Finke E-J, Grunow R. A novel screening ELISA and a confirmatory Western blot useful for diagnosis and epidemiological studies of tularemia. Epidemiol Infect. 2005;133(4):759-66.

29. Pourhossein B, Esmaeili S, Gyuranecz M, Mostafavi E. Tularemia and plague survey in rodents in an earthquake zone in southeastern Iran. Epidemiol Health. 2015;37: e2015050.

30. Mostafavi E, Shahraki AH, Japoni-Nejad A, Esmaeili S, Darvish J, Sedaghat MM, Mohammadi A, Mohammadi Z, Mahmoudi A, Pourhossein B. A field study of plague and tularemia in rodents, Western Iran. Vector-Borne Zoonotic Dis. 2017;17(4):247-53.

\section{Publisher's Note}

Springer Nature remains neutral with regard to jurisdictional claims in published maps and institutional affiliations.

Ready to submit your research? Choose BMC and benefit from:

- fast, convenient online submission

- thorough peer review by experienced researchers in your field

- rapid publication on acceptance

- support for research data, including large and complex data types

- gold Open Access which fosters wider collaboration and increased citations

- maximum visibility for your research: over $100 \mathrm{M}$ website views per year

At $\mathrm{BMC}$, research is always in progress.

Learn more biomedcentral.com/submissions 